\title{
Real-time detection of reactive oxygen species generation by marine phytoplankton using flow injection-chemiluminescence
}

\author{
Angela Milne ${ }^{*}$, Margaret S. Davey ${ }^{2}$, Paul J. Worsfold ${ }^{3}$, Eric P. Achterberg ${ }^{4}$, Alison R. Taylor ${ }^{2,5}$ \\ ${ }^{1}$ Department of Oceanography, Florida State University, Tallahassee, FL 32306, USA \\ ${ }^{2}$ Marine Biological Association, Citadel Hill, Plymouth PL1 2PB, UK \\ ${ }^{3}$ School of Earth, Ocean and Environmental Sciences, University of Plymouth, Plymouth PL4 8AA, UK \\ ${ }^{4}$ School of Ocean and Earth Science, National Oceanography Centre, University of Southampton, Southampton SO14 3ZH, UK \\ ${ }^{5}$ Department of Biology and Marine Biology, University of North Carolina Wilmington, Wilmington, NC 28403, USA
}

\begin{abstract}
Little is known about the biological production of reactive oxygen species (ROS) such as $\mathrm{H}_{2} \mathrm{O}_{2}$ and $\mathrm{O}_{2}^{-}$in the surface waters of the oceans. This article describes two flow injection-chemiluminescence methods to measure $\mathrm{H}_{2} \mathrm{O}_{2}$ and $\mathrm{O}_{2}^{-}$production by marine diatoms. These methods each incorporated a polycarbonate filter unit in which live cells were immobilized, followed by downstream determination of $\mathrm{H}_{2} \mathrm{O}_{2}$ and $\mathrm{O}_{2}^{-}$in the cell filtrate. The sample analysis rate was $\sim 1 \mathrm{~min}^{-1}$ for $\mathrm{H}_{2} \mathrm{O}_{2}$ and continuous for $\mathrm{O}_{2}^{-}$during assays with diatom cells. The respective detection limits for each system were $1.9 \mathrm{nM}\left(\mathrm{H}_{2} \mathrm{O}_{2}\right)$ and $1.6 \mathrm{nM}\left(\mathrm{O}_{2}^{-}\right)$. An initial examination of the effect of changing light intensity showed that a rapid light-induced production of both $\mathrm{O}_{2}{ }^{-}$and $\mathrm{H}_{2} \mathrm{O}_{2}$ by $T$. weissflogii cells could be readily detected. Moreover, this production was proportional to the biomass present on the flushed filter. These methods enable the monitoring of real-time fluctuations of biological ROS production in response to changing environmental conditions, and therefore facilitate analysis of the biotic component of ROS production and the subsequent impacts on chemical speciation of nutrients and trace metals in aquatic ecosystems.
\end{abstract}

\section{Introduction}

Reactive oxygen species (ROS) are ubiquitous in the surface waters of the oceans and include free radicals and peroxides, of which superoxide $\left(\mathrm{O}_{2}^{-}\right)$and hydrogen peroxide $\left(\mathrm{H}_{2} \mathrm{O}_{2}\right)$ are the principal species. These transient species are highly reactive and can be involved in many chemical interactions, including the cycling of trace metals and organic compounds in the marine environment. Detailed knowledge of ROS in surface waters of the oceans has centered on measurements of $\mathrm{H}_{2} \mathrm{O}_{2}$, the most stable ROS, with a half-life ranging from hours to days (Cooper et al. 1994; Petasne and Zika 1997; Yuan and Shiller 2001, 2005). In comparison, less is known about $\mathrm{O}_{2}^{-}$, which undergoes disproportionation to produce $\mathrm{H}_{2} \mathrm{O}_{2}$ and $\mathrm{O}_{2}$ (Cooper and Zika 1983; Petasne and Zika 1987; Moffett and

\footnotetext{
*Corresponding author: E-mail: AMilne@fsu.edu

Acknowledgments

The authors would like to thank Richard Geider (University of Essex), and Maeve Lohan and Simon Ussher (University of Plymouth) for all their help and guidance. We also thank the anonymous reviewers for their helpful comments. This work was carried out at the University of Plymouth and The Marine Biological Association (MBA) and supported by the Natural Environmental Research Council (NER/A/S/2002/00791) and the MBA.
}

Zafiriou 1990) and has a reported half-life in seawater ranging from seconds to minutes (Zafiriou 1990; Millero 2006).

The known primary in situ source of ROS involves photochemical processes as a result of the interaction of ultraviolet (UV) light with $\mathrm{O}_{2}$, dissolved organic matter, and/or trace metals (Cooper et al. 1988; Yocis et al. 2000; Kieber et al. 2003; Millero 2006). Atmospheric deposition of peroxides, particularly during wet precipitation events, also results in a significant increase in ROS concentrations in surface waters (Cooper et al. 1987; Yuan and Shiller 2000; Croot et al. 2004; Gerringa et al. 2004). In contrast, relatively little is known about the biological contributions to the ROS pool in surface waters. Recent studies have suggested that biological production of $\mathrm{H}_{2} \mathrm{O}_{2}$ may be significant (Yuan and Shiller 2005) which is further supported by positive correlations between subsurface $\mathrm{H}_{2} \mathrm{O}_{2}$ maxima and chlorophyll in the Southern Ocean (Croot et al. 2005). Moreover, Wolfe-Simon et al. (2005) indicated that phytoplankton are the most important source of ROS in the water column at the Hawaii Ocean Time Series (HOT) station ALOHA. To elucidate the relative contribution and importance of oceanic biological ROS generation, a better understanding of the underlying biological processes is required.

Cellular sources and sinks for ROS are well understood for terrestrial plants (Smirnoff 2005) and marine algae (Dring 2006). Our work centers on the role played by plasma membrane 
redox processes in ROS production and the potential function(s) of this process, such as acquisition of nutrients and redox homeostasis under physiological and physical stress. Both abiotic (e.g., light, nutrient status, and temperature) as well as biotic factors such as pathogen interactions (Evans et al. 2006) can influence the degree of oxidative stress and ROS production and release to the surrounding medium by phytoplankton. Our aim was to develop a method to detect the generation of ROS by phytoplankton cells and measure this realtime ROS production in response to changes in environmental parameters such as irradiance, temperature, salinity, nutrient supply, and metabolic inhibitors. To address this aim, methods that enable sensitive and time-resolved measurements of ROS production by phytoplankton under a variety of environmental conditions are required.

The generation of ROS has previously been examined, and a number of fluorescent probes are available that detect ROS in animal and plant cells, such as Amplex Red ${ }^{\mathrm{TM}}$ for $\mathrm{H}_{2} \mathrm{O}_{2}$ and Oxyburst ${ }^{\circledR}$ Green for $\mathrm{O}_{2}^{-}$(Molecular Probes, Invitrogen). We initially examined the efficacy of these fluorometric batch methods by incubating diatom cells with the probes and monitoring the change in fluorescence over time according to manufacturer's instructions. We were able to detect phytoplankton ROS production using these probes (Davey et al. data not shown); however, the sensitivity of the probes $(\mu \mathrm{M})$, reaction time, and cost of the reagents in conjunction with the spectrophotometric batch method of detection meant ROS production could not be readily adapted to a continuous flow detection system. Spectrophotometric assays of $\mathrm{O}_{2}^{-}$ production using ferrocytochrome c (Butler et al. 1982; Fridovich 1985) or the tetrazolium dyes nitro-blue tetrazolium (Pipe 1992), 2,3-bis(2-methoxy-4-nitro-5-sulfophenyl)-2Htetrazolium-5-carboxanilide (XTT) (Ukeda et al. 1997), and water-soluble tetrazolium (WST-1) (Sutherland and Learmonth 1997; Tan and Berridge 2000) were found to be unsuitable because of high nonspecific background turnover of the probe and uptake by the diatom cells (Davey et al. data not shown).

Chemiluminescence methods based on the oxidation of luminol (5-amino-2,3-dihydro-1,4-phthalazinedione) by $\mathrm{H}_{2} \mathrm{O}_{2}$ and MCLA [2-methyl-6-(4-methoxyphenyl)-3,7-dihydroimidazo[1,2-a]pyrazin-3(7H)-one hydrochloride] by $\mathrm{O}_{2}^{-}$have been respectively used to determine $\mathrm{H}_{2} \mathrm{O}_{2}$ concentrations in aquatic ecosystems (Yuan and Shiller 1999) and ROS production by phytoplankton (Lee et al. 1995; Kim et al. 2000, 2004; Zheng et al. 2003; Kustka et al. 2005; Rose et al. 2008b). We therefore used these two chemiluminescent probes to develop a flow injection-chemiluminescence system for both $\mathrm{H}_{2} \mathrm{O}_{2}$ and $\mathrm{O}_{2}^{-}$analyses. Each flow system incorporated an in-line transparent filter unit to immobilize phytoplankton cells upstream of the detector, an approach previously used by Kustka et al. (2005) and Rose et al. (2005) for studies focusing on the role of $\mathrm{O}_{2}^{-}$production in iron speciation. In this system, the filter-supported cells were constantly flushed with media, and the environmental conditions could be manipulated without interfering with downstream detection of ROS in the filtrate solution. In contrast to both Kustka et al. (2005) and Rose et al. (2005), the system developed here was designed to monitor real-time production of both $\mathrm{H}_{2} \mathrm{O}_{2}$ and $\mathrm{O}_{2}^{-}$by phytoplankton cells. To allow manipulation of environmental factors that regulate cellular ROS production, cells were preloaded into an in-line filter unit that could be exposed to various light levels, an approach not previously used. The system developed was sufficiently flexible to enable sensitive real-time measurements of ROS generation while manipulating the physical and chemical environment of the cells. Although the present study focused on one diatom species, the system can be readily adapted for a wide range of phytoplankton species.

\section{Materials and procedures}

$\mathrm{H}_{2} \mathrm{O}_{2}$ was measured by the metal [Co(II)] catalyzed oxidation of luminol (adapted from Price et al. 1994). Modifications were made to the original method; the sample injection loop was reduced to $60 \mu \mathrm{L}$, and the previously separate reagents were mixed to a single combined luminol/Co(II) reagent solution (Fig. 1a). For $\mathrm{O}_{2}^{-}$detection, we developed a method based on the chemiluminescent probe MCLA (Lee et al. 1995; Asai et al. 1999; Zheng et al. 2003). The coastal diatom Thalassiosira weissflogii was used in the preliminary investigation of phytoplankton ROS production, and the protocols were optimized for physiologically relevant $\mathrm{pH}(\sim 8.1)$.

Instrumentation-Parallel $\mathrm{H}_{2} \mathrm{O}_{2}$ and $\mathrm{O}_{2}^{-}$measurements were carried out using flow injection systems. Schematic diagrams of the two manifolds are illustrated in Fig. 1. Both systems consisted of a peristaltic pump (Gilson Minipuls; Anachem) and an end-window photomultiplier tube (PMT, Thorn EMI 9789QA) housing a coiled quartz flow cell. High power voltage was supplied to the PMT using a $1.1-\mathrm{kV}$ power supply (PM 28B, Thorn EMI). The continuous PMT voltage output was amplified and filtered (LPF-100A, Low Pass Bessel Filter 4 Pole; Warner Instruments) and then digitized (Minidigi 1A; Axon Instruments). Peak detection and offline analysis was performed using Axoscope 9.0 and Clampfit 9.0 software (Axon Instruments).

The $\mathrm{H}_{2} \mathrm{O}_{2}$ manifold contained a six-port, two-position rotary injection valve (Anachem) with a $60-\mu \mathrm{L}$ sample loop for manual sample injection. For $\mathrm{O}_{2}{ }^{-}$analyses, a continuous flow system was used, consisting of a T-piece to mix sample and reagent immediately before entering the quartz flow cell; the T-piece was positioned directly in front of the PMT.

All tubing for both manifolds was PTFE $(0.75 \mathrm{~mm}$ i.d.; Fisher Scientific), with the exception of a mixing baffle (silicone; Elkay) and the peristaltic pump tubing (flow-rated sili-

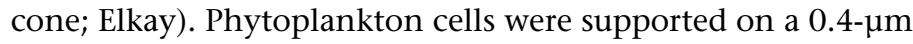
polycarbonate filter (Whatman Cyclopore ${ }^{\mathrm{TM}}$ ) held within a clear polycarbonate $25-\mathrm{mm}$ in-line filter holder (Sartorius). The whole filter unit was attached to the sample lines using 
a

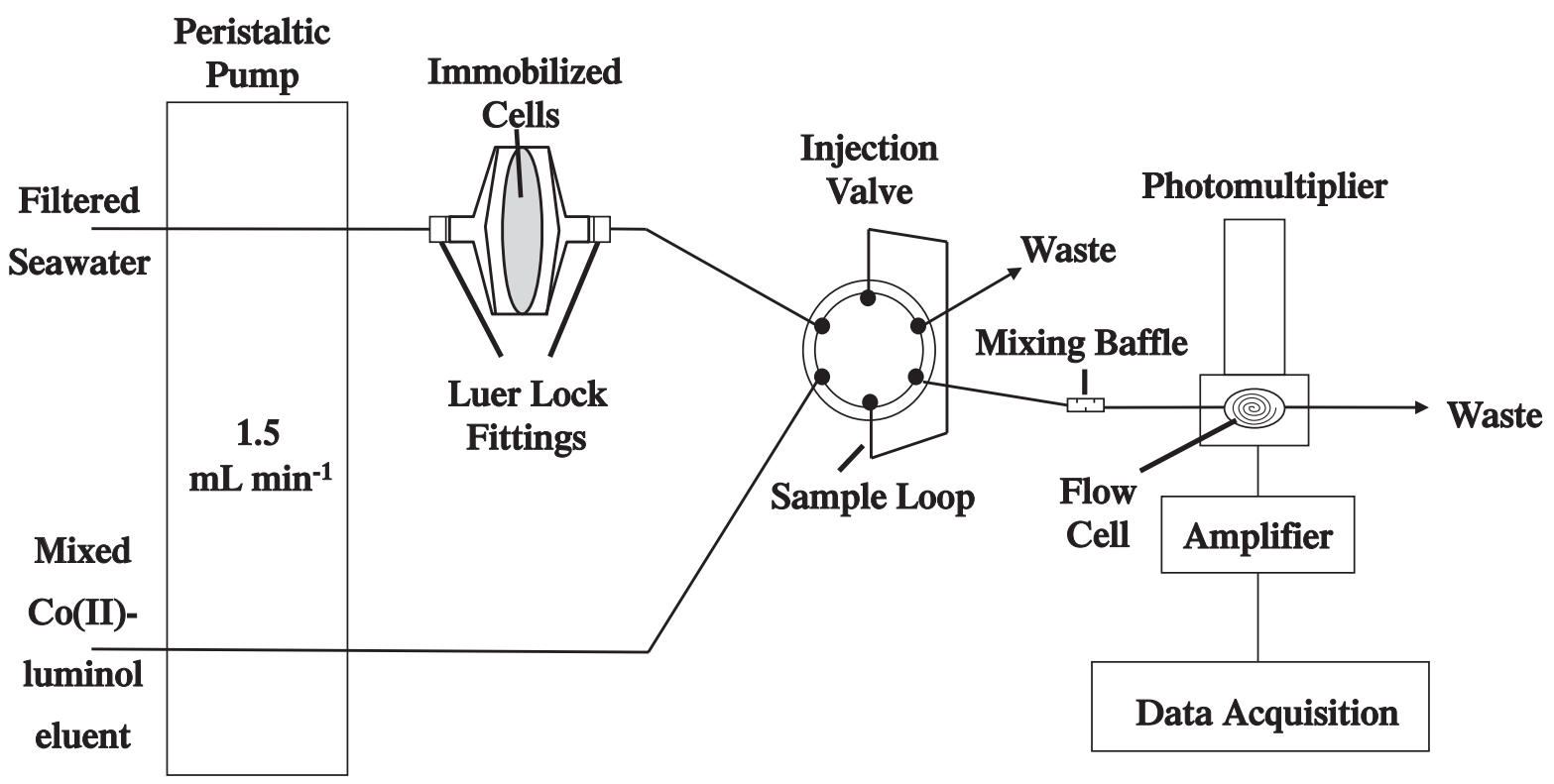

b

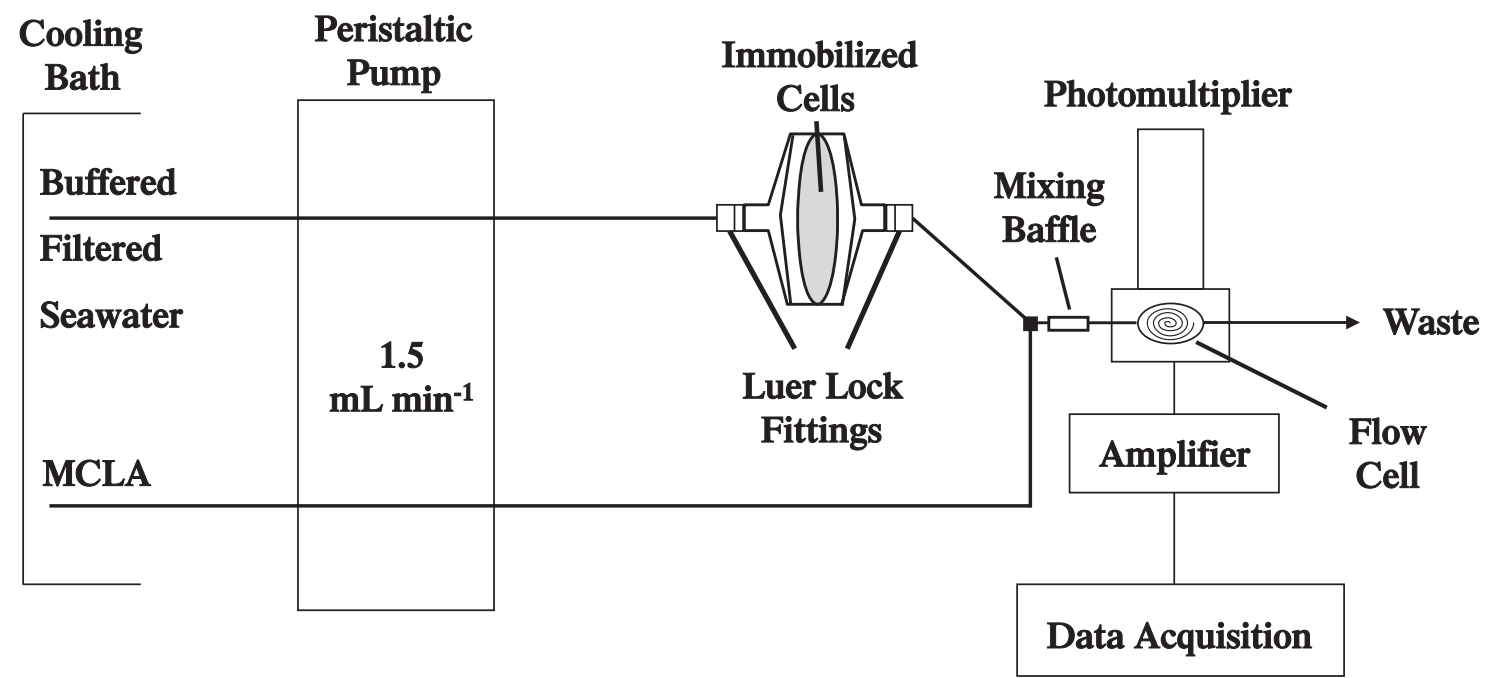

Fig. 1. Schematic diagrams of the manifolds for the determination of $\mathrm{H}_{2} \mathrm{O}_{2}$ (a) and $\mathrm{O}_{2}^{-}$(b).

luer lock connectors (Cole Parmer). Photosynthetically active radiation was provided using a fiber optic lamp (Schott Mainz, K450B), directed onto the cells.

Reagents-All reagents were obtained from Sigma-Aldrich unless otherwise stated and were prepared with ultra-high purity (UHP, Millipore, $18 \mathrm{M} \Omega \mathrm{cm}^{-1}$ ) water. Stock solutions of $0.03 \mathrm{M}$ luminol and $0.05 \mathrm{M} \mathrm{Co}\left(\mathrm{NO}_{3}\right)_{2} \cdot 6 \mathrm{H}_{2} \mathrm{O}$ (Fluka) were prepared in $0.1 \mathrm{M} \mathrm{NaCO}_{3}$ and left for $24 \mathrm{~h}$. From the stock solutions, a mixed reagent working solution of luminol/Co(II) $\left(3 \times 10^{-5} \mathrm{M} / 5 \times 10^{-4} \mathrm{M}\right)$ was prepared in $0.1 \mathrm{M} \mathrm{Na}_{2} \mathrm{CO}_{3}$ buffer, and the $\mathrm{pH}$ was adjusted to 10.8 with $\mathrm{HCl}(12 \mathrm{M}$, AnalaR; Fisher Scientific) and left for $24 \mathrm{~h}$. The stock and working solutions were stored at $4^{\circ} \mathrm{C}$. Catalase (bovine liver), when used, was added to yield a final concentration of $1-3 \mathrm{U} \mathrm{mL}^{-1}$.

MCLA stock (100 $\left.\mathrm{mg} \mathrm{mL}^{-1}\right)$ (Fluka) was prepared and stored at $-80^{\circ} \mathrm{C}$. Fresh MCLA reagent, comprising $9 \mu \mathrm{M}$ MCLA in 100:1 vol/vol UHP water/ethanol, $0.5 \mathrm{mM}$ HEPES ( $\mathrm{N}-(2-$ hydroxyethyl) piperazine- $N$ '-2-ethanesulfonic acid) $(\mathrm{pH} \mathrm{8.1)}$ 
was prepared according to Zheng et al. (2003) immediately before use and stored on ice throughout the assay. DTPA (diethylenetriaminepenta-acetic acid) $(100 \mu \mathrm{M})$ was added to all reagents used in the $\mathrm{O}_{2}{ }^{-}$assay to minimize metal-catalyzed Fenton chemistry in the analytical manifold (Kustka et al. 2005; Rose and Waite 2005; Rose et al. 2005). SOD (bovine erythrocyte), when used, was added to a final concentration of 2-4 $\mathrm{U} \mathrm{mL}^{-1}$.

Filtered seawater (FSW)-Seawater $(60 \mathrm{~L})$ from the English Channel $\left(50^{\circ} 09.55 \mathrm{~N} 04^{\circ} 14.66 \mathrm{~W}\right)$ was collected from a depth of $65.5 \mathrm{~m}$ using a CTD carousel and Go-Flo bottles. This seawater was filtered ( $0.2 \mu \mathrm{m}$ Sartobran P; Sartorius) and aged at room temperature in the dark for at least 2 weeks. This lowbackground ROS seawater was used for all standard solutions, calibrations, and experimental assays. In the $\mathrm{O}_{2}^{-}$assays, batches of this filtered seawater were buffered with $0.5 \mathrm{mM}$ HEPES (HbFSW) at pH 8.1-8.2 (see "pH optimization" under "Assessment").

Phytoplankton culture-Batch cultures of T. weissflogii were incubated at $15^{\circ} \mathrm{C}, 150 \mu \mathrm{mol}$ photons $\mathrm{m}^{-2} \mathrm{~s}^{-1}, 12: 12$ light/dark cycle in filtered seawater supplemented with $500 \mu \mathrm{M} \mathrm{NaNO}$, $32 \mu \mathrm{M} \mathrm{K}_{2} \mathrm{HPO}_{4}, 100 \mu \mathrm{M} \mathrm{Na} \mathrm{SiO}_{3}$, and Guillard's F/2 vitamins and a trace metal solution containing $2.8 \mu \mathrm{M} \mathrm{Na}$-EDTA, 80 $\mathrm{nM} \mathrm{ZnSO}{ }_{4}, 460 \mathrm{nM} \mathrm{MnCl}_{2}, 50 \mathrm{nM} \mathrm{CoCl}_{2}, 20 \mathrm{nM} \mathrm{CuSO}_{4}, 2 \mu \mathrm{M}$ $\mathrm{Na}_{2} \mathrm{MoO}_{4}$, and $200 \mathrm{nM} \mathrm{H}_{2} \mathrm{SeO}_{3}$. Iron was added separately as a 1:1.36 solution of $\mathrm{FeCl}_{3}$ and $\mathrm{Na}_{2}$-EDTA to a final concentration of $1 \mu \mathrm{M}$ Fe and $1.36 \mu \mathrm{M}$ EDTA. Cultures were maintained in mid- to late log phase by routine subculture. T. weissflogii cells were harvested and concentrated by filtration ( $3 \mu \mathrm{m}$ polycarbonate, $47 \mathrm{~mm}$; Whatman Cyclopore ${ }^{\mathrm{TM}}$ ), washed, and resuspended in FSW. Resuspended cells were acclimated in the dark for at least 20 min before use in experiments. Cell counts were determined using a hemocytometer (improved Neubauer slide), and samples were either counted immediately or preserved by the addition of Lugol solution (100:1 vol/vol culture:Lugol).

Procedure-The two manifolds were configured as detailed in Fig. 1; before and after each experimental run, they were cleaned with $0.5 \mathrm{M} \mathrm{HCl}$ followed by flushing with UHP water. The addition of a mixing baffle in both systems ensured complete mixing of the sample and reagent before entering the detection flow cell. Before ROS assays, both systems were operational (flowing with reagents and FSW/HbFSW) for at least 30 min to establish baseline stability and ensure that all tubing and sample lines were conditioned. Transparent filter holders containing 25-mm (0.4- $\mu \mathrm{m}$ Whatman Cyclopore) membrane filters were prefilled with FSW/HbFSW to remove air bubbles from the units. Equal volumes of washed, dark-adapted cells were slowly transferred, by syringe, onto the membrane filters supported in the filter holders. This procedure was performed with a gentle swirling motion to ensure even distribution of the cells over the filter. Once loaded with cells, the filter units were placed in the sample line of each manifold using the luer lock connectors. To acclimate cells to the flow conditions of the manifolds, the cells were perfused with either FSW $\left(\mathrm{H}_{2} \mathrm{O}_{2}\right)$ or HbFSW $\left(\mathrm{O}_{2}^{-}\right)$in the dark for $15 \mathrm{~min}$ before the start of assays. This acclimation was performed to ensure that any subsequent changes in signal were in response to light exposure only and not an artifact of the necessary manipulation associated with loading the in-line filter units. A flow rate of $1.5 \mathrm{~mL} \mathrm{~min}{ }^{-1}$ was maintained throughout the experiments. Assays typically lasted 1-2 h, during which time the immobilized cells were intermittently exposed to varying light levels (30-500 $\mu \mathrm{mol}$ photons $\mathrm{m}^{-2} \mathrm{~s}^{-1}$ ) and the filtrate was analyzed. Between each light period, the immobilized cells were returned to the dark until the ROS signal returned to a steady-state value, typically close to the baseline. Manual injections of the FSW filtrate were performed $\left(\sim 1\right.$ injection $\left.\mathrm{min}^{-1}\right)$ to determine the $\mathrm{H}_{2} \mathrm{O}_{2}$ production by the cells. In $\mathrm{O}_{2}{ }^{-}$assays, filtrate was mixed directly with the MCLA reagent stream and the $\mathrm{O}_{2}^{-}$concentration was monitored continuously. Before calibration, the filter units were bypassed and standards were either injected $\left(\mathrm{H}_{2} \mathrm{O}_{2}\right)$ or pumped $\left(\mathrm{O}_{2}^{-}\right)$through the sample line.

The photochemical generation of ROS in the absence of biomass was measured using the same apparatus in the absence of microalgal cells. Additionally, the enzymes catalase and SOD were used to establish the specificity of the two ROS assays; these enzymes were added to either FSW or HbFSW of the respective $\mathrm{H}_{2} \mathrm{O}_{2}$ or $\mathrm{O}_{2}^{-}$flow system.

\section{Assessment}

pH optimization-The chemiluminescence reactions (quantum efficiency) of both $\mathrm{H}_{2} \mathrm{O}_{2}$ and $\mathrm{O}_{2}^{-}$with their respective chemiluminescent probes, luminol and MCLA, are highly $\mathrm{pH}$ sensitive. To establish the optimum $\mathrm{pH}$ of the mixed luminol/Co(II) reagent, five solutions with $\mathrm{pH}$ varying from 9.2 to 11.5 were prepared. The reagent was buffered with $0.1 \mathrm{M}$ $\mathrm{Na}_{2} \mathrm{CO}_{3}$ and the $\mathrm{pH}$ adjusted through the addition of concentrated $\mathrm{HCl}$. The optimum chemiluminescence response for $\mathrm{H}_{2} \mathrm{O}_{2}$ was recorded at $\mathrm{pH} 10.8$ using a $100 \mathrm{nM}$ standard prepared in FSW. This is consistent with the $\mathrm{pH}$ optimum reported by Price et al. $(1994,1998)$ using a system with separate luminol and $\mathrm{Co}(\mathrm{II})$ reagent streams.

In preliminary experiments, we found that mixing of the MCLA reagent with the FSW led to large changes in chemiluminescence signal which were independent of $\mathrm{O}_{2}^{-}$concentration and could not be quenched by conventional SOD levels (data not shown). This was most likely due to the large $\mathrm{pH}$ difference between the MCLA reagent and sample, given that previous studies investigating the determination of $\mathrm{O}_{2}^{-}$have shown a strong $\mathrm{pH}$ dependence of the MCLA signal (Lee et al. 1995, Ukeda et al. 1997). To avoid artifacts due to $\mathrm{pH}$ shifts during our experiments, we therefore buffered both FSW and MCLA reagent with $0.5 \mathrm{mM}$ HEPES to $\mathrm{pH} 8.1-8.2$, the physiological $\mathrm{pH}$ appropriate for the phytoplankton cells. Although this $\mathrm{pH}$ is not optimal for $\mathrm{O}_{2}^{-}$-mediated MCLA chemiluminescence ( $\mathrm{pH} 9.2$, Lee et al. 1995), the $\mathrm{O}_{2}^{-}$-specific MCLA chemiluminescence in the buffered FSW was sufficient to enable 
successful monitoring of $\mathrm{O}_{2}^{-}$generated by phytoplankton cells at the physiological $\mathrm{pH}$ necessary while eliminating the luminescence artifacts associated with reagent mixing and $\mathrm{pH}$ shifts during the experiments.

Flow rates-When establishing the optimal flow rate for the two ROS systems, the maintenance of viable immobilized cells within the filter unit also had to be taken into consideration. In the absence of cells, the optimal flow for the $\mathrm{H}_{2} \mathrm{O}_{2}$ system was determined to be $1.5 \mathrm{~mL} \mathrm{~min}^{-1}$, the maximum response from replicate injections of a $50 \mathrm{nM}$ standard prepared in FSW. This flow rate was then tested in the presence of cells supported in the filter unit, and subsequent microscopic inspection confirmed that this optimal perfusion rate did not damage the diatom cells. To maintain comparability between the two ROS systems, the flow rate for $\mathrm{O}_{2}^{-}$detection was matched to that of $\mathrm{H}_{2} \mathrm{O}_{2}$ at $1.5 \mathrm{~mL} \mathrm{~min}^{-1}$. To minimize signal loss of the $\mathrm{O}_{2}^{-}$radical, the residence time between the filter unit and detector was reduced and an optimal signal was achieved by inserting a short length of wide-bore silicone tubing $(3.5 \mathrm{~mm}$ i.d.) between the T-piece mixing junction and the flow cell (Fig. 1b).

Standardization-The two flow systems were individually calibrated before and after each ROS assay experiment. A primary working stock solution of $\mathrm{H}_{2} \mathrm{O}_{2}$ was prepared daily in FSW from a stock solution of $\mathrm{H}_{2} \mathrm{O}_{2}(30 \%$, AnalaR; Fisher Scientific). $\mathrm{H}_{2} \mathrm{O}_{2}$ standards in the range 10-200 nM were prepared from the primary working stock solution, immediately analyzed, and used to generate calibration graphs. Replicate analyses $(n=4)$ were performed for all standard solutions, and standard graphs were typically linear in response (Fig. 2). The stock solution of $\mathrm{H}_{2} \mathrm{O}_{2}$ was periodically standardized using potassium permanganate titrations (Vogel 1989).

The $\mathrm{O}_{2}^{-}$system was calibrated indirectly, using the substrate xanthine and enzyme xanthine oxidase (X:XO) to generate $\mathrm{O}_{2}^{-}$in $\mathrm{HbFSW}$ solutions. This relatively simple method of calibration was easy to use when combining the two ROS systems and was preferred over the alternative approach of photochemical production of $\mathrm{O}_{2}^{-}(\mathrm{McD}$ owell et al. 1983) that was used by previous workers (Goldstone and Voelker 2000; Kutska et al. 2005; Rose et al. 2005). Duplicated sets of standard solutions were prepared by adding $5-50 \mathrm{mU} \mathrm{mL} \mathrm{mL}^{-1}$ xanthine oxidase (xanthine:oxygen oxidoreductase) to $100 \mu \mathrm{M}$ xanthine in HbFSW immediately before use. One set was used to assess the chemiluminescent MCLA signal, the second set to determine $\mathrm{X}: \mathrm{XO}$ superoxide production rates by spectrophotometry. The $\mathrm{O}_{2}^{-}$production rate of the $\mathrm{X}$ :XO standard solutions was analyzed by following the reduction of the soluble tetrazoleum salt 2,3-bis(2-methoxy-4-nitro-5-sulfophenyl)2H-tetrazolium-5-carboxanilide (XTT) $(7 \mu \mathrm{M})$ over $30 \mathrm{~min}$ (Ukeda et al. 1997), and the rate was calculated using a molar absorptivity at $\lambda_{470} \mathrm{~nm}$ of $21,600 \mathrm{M}^{-1} \mathrm{~cm}^{-1}$ (Sutherland and Learmonth 1997). XTT was reduced at a constant rate over 30 min in the presence of the $\mathrm{X}: \mathrm{XO}$ enzyme couple, indicating constant $\mathrm{O}_{2}^{-}$generation in the standards over this time

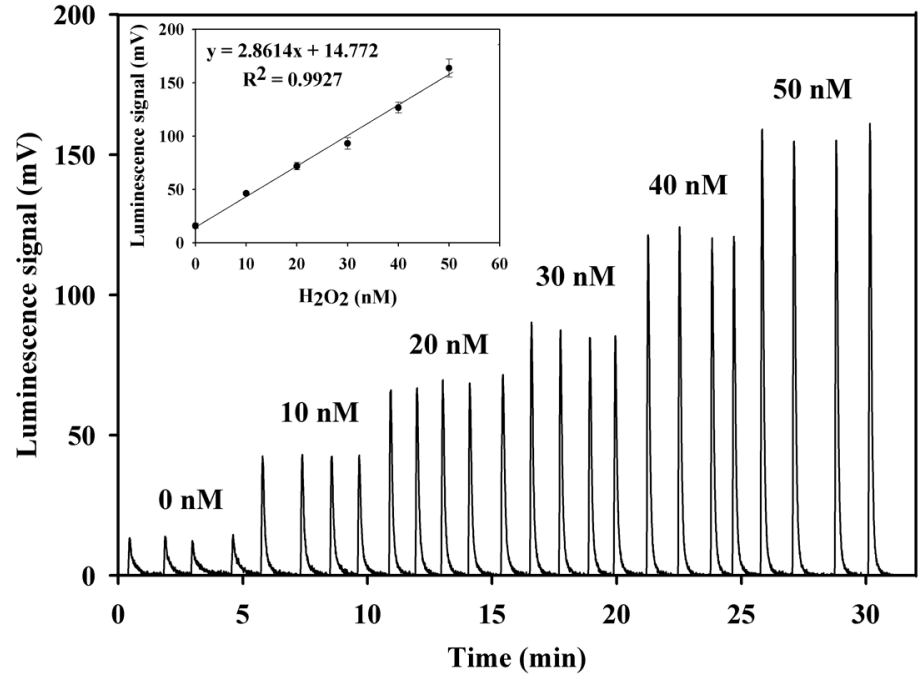

Fig. 2. Instrument calibration for $\mathrm{H}_{2} \mathrm{O}_{2}$. The PMT voltage signal was recorded in response to standard additions of $10-50 \mathrm{nM} \mathrm{H}_{2} \mathrm{O}_{2}$ in FSW. An average of the four injection peaks for every standard was used to generate the subsequent calibration (inset, error bars represent two standard deviations).

period. For quantification, it is necessary to know the rate of $\mathrm{O}_{2}^{-}$decay in the standards. Studies have shown that the rate of $\mathrm{O}_{2}^{-}$decay depends on $\mathrm{pH}$ (Bielski et al. 1985; Zafiriou 1990). More recently, Rose et al. (2008a,b) discussed the varying physiochemical properties of a solution which can influence $\mathrm{O}_{2}^{-}$concentrations and in turn affect the decay rate. They report varying half-lives of $71 \mathrm{~s}$ to $16 \mathrm{~min}$ based on calculated decay rate constants for individual seawater samples. For the purposes of this initial study, we assumed a half-life in seawater of $100 \mathrm{~s}$ (Millero 2006). The concentration of $\mathrm{O}_{2}^{-}$in each standard was calculated at 1-min intervals, using the production rates determined spectrophotometrically and the half-life of $100 \mathrm{~s}$. The best-estimate $\mathrm{O}_{2}{ }^{-}$concentration for each standard was the average calculated concentration between 6 and $10 \mathrm{~min}$ after addition of XO. Calibrations curves were generated by plotting the relative increase in the MCLA signal in response to the $\mathrm{X}: \mathrm{XO}$ standards (Fig. 3a) against the $\left[\mathrm{O}_{2}^{-}\right]$calculated for those standards (Fig. 3b). Calibrations were carried out daily.

The specificity of MCLA to the detection of $\mathrm{O}_{2}{ }^{-}$was examined by using an $\mathrm{H}_{2} \mathrm{O}_{2}$ standard (100 $\mathrm{nM}$ in HbFSW). No signal response to this relatively high $\mathrm{H}_{2} \mathrm{O}_{2}$ concentration was observed (data not shown). Luminol, on the other hand, is not $\mathrm{H}_{2} \mathrm{O}_{2}$ specific, as both hydroxyl (or hydroxyl-like) radicals and $\mathrm{O}_{2}^{-}$can have a significant effect on the luminol chemiluminescent signal (Rose and Waite 2001). However, the use of an injection valve with sample loop in the $\mathrm{H}_{2} \mathrm{O}_{2}$ system introduces a short delay before sample analyses. This delay allows for slight aging of the sample, which, coupled with the residence time of the sample in the filter holder and the short lifetime of $\mathrm{O}_{2}^{-}$, minimizes the interference from this species. The specificity of the two systems to their respective ROS species 
a

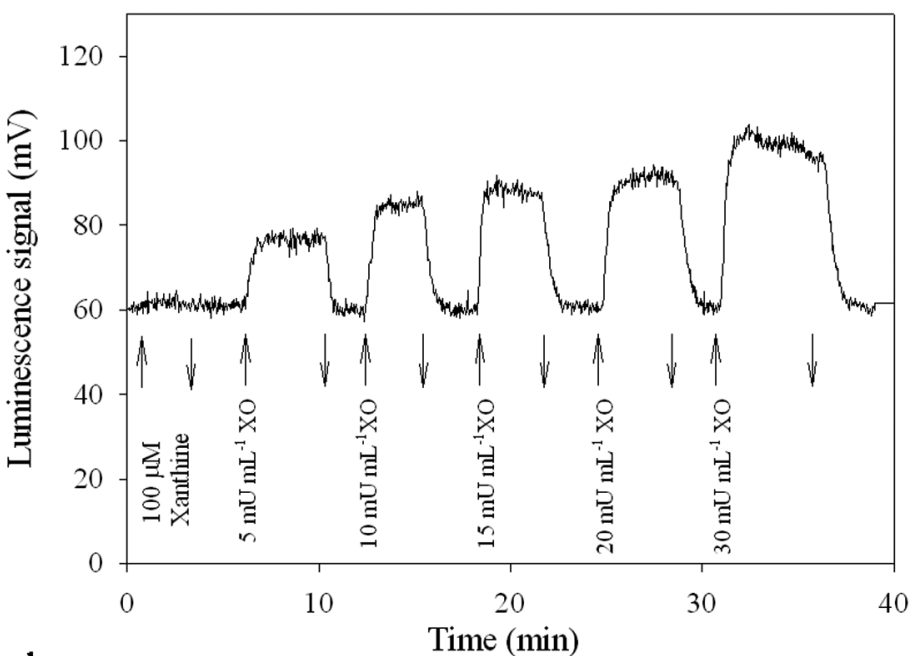

b

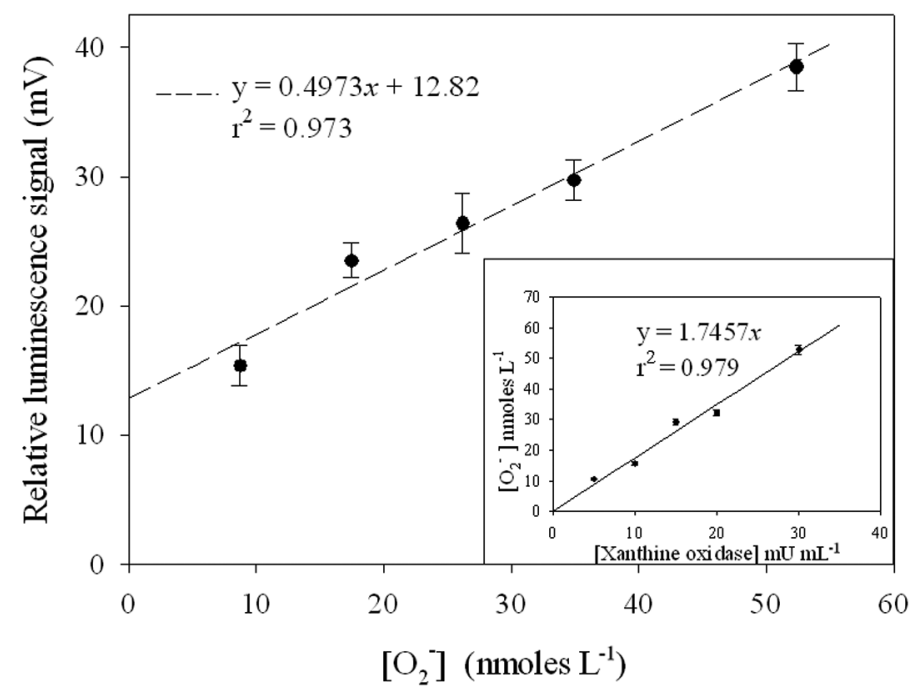

Fig. 3. Calibration of the $\mathrm{O}_{2}^{-}$-dependent MCLA signal. (a) Trace showing standard additions of 5-30 $\mathrm{mU}$ xanthine oxidase in $100 \mu \mathrm{M}$ of the substrate xanthine added to the reagent flow. (b) The $\mathrm{O}_{2}^{-}$MCLA signal was indirectly calibrated, the standard addition solutions were analyzed spectrophotometrically $\left(\lambda_{470}\right)$, and the $\mathrm{O}_{2}^{-}$production rate was determined by following the reduction of the soluble tetrazolium salt XTT using a molar absorptivity of $21,600 \mathrm{M}^{-1} \mathrm{~cm}^{-1}$ (inset). The XTT calibration of $\mathrm{O}_{2}^{-}$production was then used to derive a calibration of MCLA luminescence signal versus $\mathrm{O}_{2}^{-}$production rate.

was further confirmed by the signal quenching following catalase and SOD additions (see Fig. 4).

Analytical figures of merit-Table 1 displays the figures of merit for both detection systems. For the $\mathrm{H}_{2} \mathrm{O}_{2}$ system, the analytical blank was determined using low ROS FSW, which was analyzed in the same manner as the standards and includes any signal associated with the reagents and the manifold. The detection limit was defined as the hydrogen peroxide concentration corresponding to the signal of three times the standard deviation on replicate analyses of the analytical blank $(n=4)$. When considering the mean data for the assay
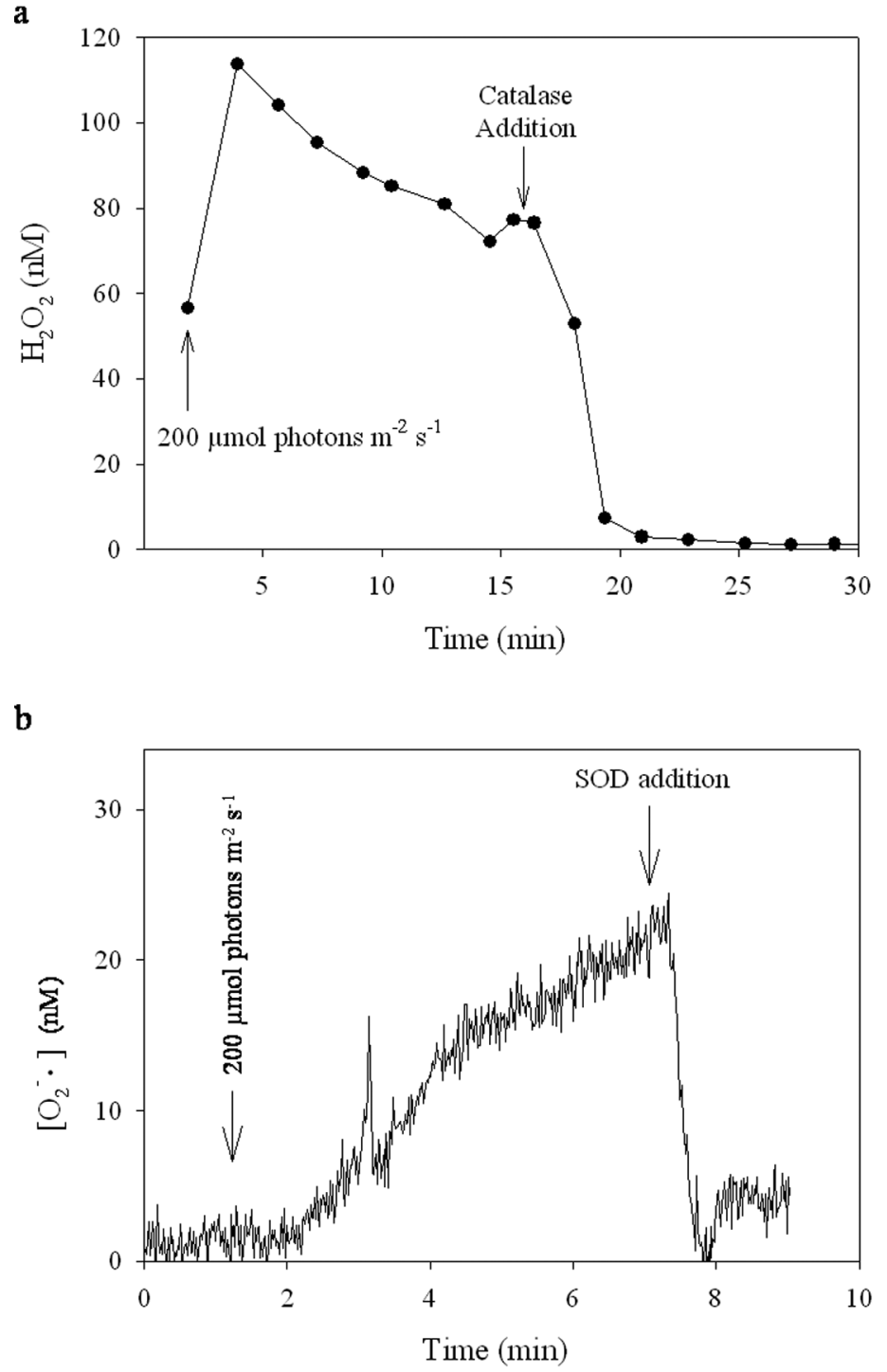

Fig. 4. Specificity of ROS species production and detection. Representative traces showing that in the presence of $T$. weissflogii cells, light-stimulated increase in luminol signal was completely quenched by $1-3 \mathrm{U} \mathrm{mL}^{-1}$ of the $\mathrm{H}_{2} \mathrm{O}_{2}$ scavenging enzyme catalase (a) and light-stimulated increase in MCLA luminescence signal was completely quenched by $2-4 \mathrm{U} \mathrm{mL}^{-1}$ units of SOD (b).

experiments performed, this corresponded to a detection limit of $1.9 \mathrm{nM}(n=28)$. Owing to the continuous flow design of the $\mathrm{O}_{2}^{-}$system, the operational analytical blank was defined as the baseline produced from the mixing of the two streams (MCLA and HbFSW) in the absence of cells. The detection limit of 1.6 $\mathrm{nM}$ was obtained from the analysis of baseline signal noise. The average value of the baseline was calculated over a 15-min period. The operational lower limit for the detection of $\mathrm{O}_{2}^{-}$ was defined as two times the baseline signal.

Biological production of ROS-Assays were performed to determine ROS production by microalgae and how this may be influenced by light. The compact transparent filter holders 
Table 1. Analytical figures of merit.

\begin{tabular}{lcc}
\hline & $\mathbf{H}_{2} \mathbf{O}_{2}$ & $\mathbf{O}_{2}^{-}$ \\
\hline Detection Limit & 1.9 & 1.6 \\
Precision, RSD $(\%)^{\mathrm{a}}$ & $1.4(n=4)$ & $6.7(n=7)$ \\
Sensitivity & $3.9 \pm 1.9 \mathrm{mV} \mathrm{nM}^{-1}(n=9)$ & $1.6 \pm 0.3 \mathrm{mV} \mathrm{nM}^{-1}(n=7)$ \\
Linear Range & $10-200$ & $5-60$ \\
Sample Throughput & $60 \mathrm{~h}^{-1}$ & Continuous \\
\hline
\end{tabular}

All data given in $\mathrm{nM}$ (unless otherwise indicated). The figures represent all data gathered during the assay experiments.

aPrecision is calculated as the percent relative standard deviation (\% RSD) and based on repeatability between replicate measurements of peak height for a $100 \mathrm{nM}$ standard $\left(\mathrm{H}_{2} \mathrm{O}_{2}\right)$ and $50 \mu \mathrm{M}$ xanthine and $30 \mathrm{mU}$ $\mathrm{mL}^{-1}$ xanthine oxidase $\left(\mathrm{O}_{2}^{-}\right)$.

were readily illuminated with the light source or shielded using aluminum foil during light and dark exposures. The small volume of the filter holder $(2.5 \mathrm{~mL})$ together with the flow rate used resulted in a relatively short residence time $(\sim 1.7 \mathrm{~min})$. During assays, immobilized cells were exposed to three different light intensities, 30, 150, and $500 \mu \mathrm{mol}$ photons $\mathrm{m}^{-2} \mathrm{~s}^{-1}$. Initial control experiments in the absence of cells were performed to assess any abiotic photochemical generation of $\mathrm{H}_{2} \mathrm{O}_{2}$ and $\mathrm{O}_{2}^{-}$in FSW and HbFSW. Small increases in signal were observed for both ROS systems when filter units alone were exposed to irradiances above $150 \mu \mathrm{mol}$ photons $\mathrm{m}^{-2} \mathrm{~s}^{-1}$ (Fig. 5). In the presence of cells in the filter unit however, large rapid light-dependent $\mathrm{H}_{2} \mathrm{O}_{2}$ and $\mathrm{O}_{2}^{-}$signals were observed at all light intensities $\left(30,150\right.$, and $500 \mu \mathrm{mol}$ photons $\left.\mathrm{m}^{-2} \mathrm{~s}^{-1}\right)$ (Fig. 6). The peak background signals (Fig. 5) were $<10 \%$ of the rapid lightdependent responses observed in the presence of cells (Fig. 6). Any signal associated with control experiments, which also includes any signal associated with the reagents and manifold, was deducted from signals in subsequent assays.

These assay experiments demonstrated that it is possible to monitor, in real time, with great sensitivity the effect of light exposure on the production of ROS by T. weissflogii. Moreover, the specificity of the $\mathrm{H}_{2} \mathrm{O}_{2}$ and $\mathrm{O}_{2}^{-}$production by $T$. weissflogii was demonstrated by the rapid quenching of the signal upon addition of catalase (Fig. 4a) and SOD (Fig. 4b) to the respective FSW and HbFSW flowing over the cells.

To calculate ROS production, the signal generated from the assay was multiplied by the flow rate and divided by the number of cells present on the filters. Based on this calculation, lightstimulated production rates of $1.1 \times 10^{-16}$ and $6.6 \times 10^{-16} \mathrm{~mol}$ $\mathrm{H}_{2} \mathrm{O}_{2}$ cell $^{-1} \mathrm{~h}^{-1}$ and $2.5 \times 10^{-16}$ and $13.2 \times 10^{-16} \mathrm{~mol} \mathrm{O}_{2}^{-}$cell $^{-1} \mathrm{~h}^{-1}$ were estimated for $T$. weissflogii when exposed to low (30 $\mu \mathrm{mol}$ photons $\mathrm{m}^{-2} \mathrm{~s}^{-1}$ ) and high (500 $\mu \mathrm{mol}$ photons $\mathrm{m}^{-2} \mathrm{~s}^{-1}$ ) light, respectively. In batch analysis, we observed dark rates of $\mathrm{H}_{2} \mathrm{O}_{2}$ production in $T$. weissflogii using the fluorescent probe Amplex $\operatorname{Red}^{\mathrm{TM}}\left(3.1 \times 10^{-16} \mathrm{~mol} \mathrm{H}_{2} \mathrm{O}_{2}\right.$ cell $^{-1} \mathrm{~h}^{-1}$, data not shown), and our FI-CL data also correspond to results reported by Kustka et al. (2005) for dark $\mathrm{O}_{2}^{-}$production $\left(8.4 \times 10^{-16} \mathrm{~mol} \mathrm{O}_{2}^{-}\right.$cell $\left.{ }^{-1} \mathrm{~h}^{-1}\right)$.

Relationship between ROS signal and biomass-Finally, to further test the in-line ROS detection system, we predicted that

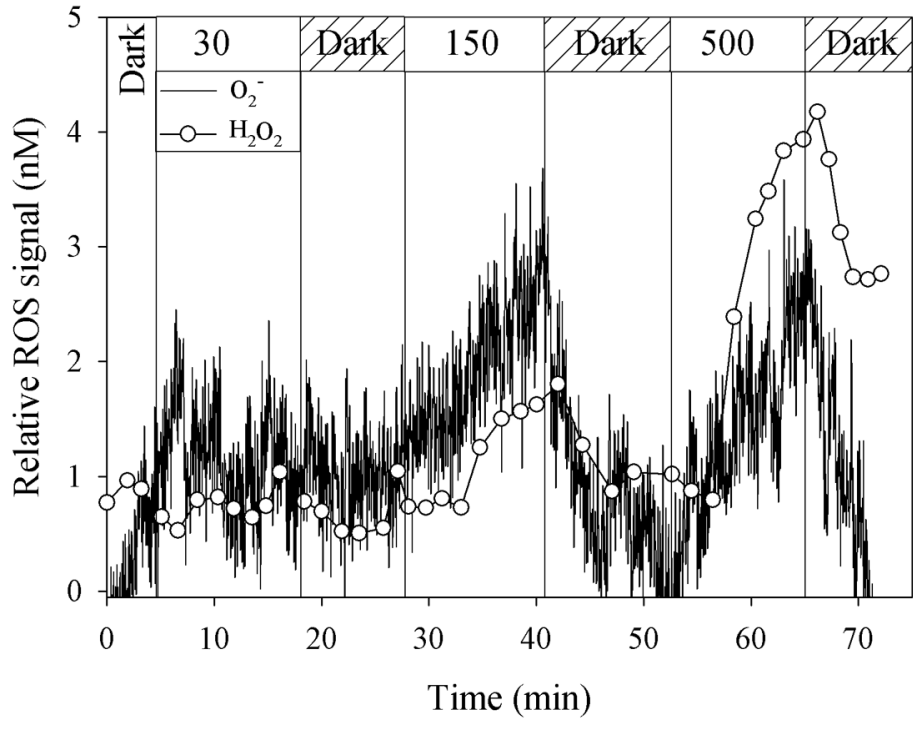

Fig. 5. Background changes in luminol $\left(\mathrm{H}_{2} \mathrm{O}_{2}\right)$ and $\mathrm{MCLA}\left(\mathrm{O}_{2}^{-}\right)$luminescence signal in response to light. Representative light response data are presented from control experiments in the absence of cells. The filter unit was maintained in the dark and exposed to periods of light ( $\mu \mathrm{mol}$ photons $\mathrm{m}^{-2} \mathrm{~s}^{-1}$ ) as indicated in the upper bar.

biological production of ROS would be proportional to the biomass present. We examined this by sequentially increasing the number of cells that were immobilized on a filter while keeping the irradiance treatment the same. In these experiments, both $\mathrm{H}_{2} \mathrm{O}_{2}$ and $\mathrm{O}_{2}^{-}$production were clearly proportional to the biomass present on the filter (Fig. 7).

\section{Comments and recommendations}

We developed two flow injection systems that are capable of sensitive, real-time analysis of phytoplankton ROS production while simultaneously enabling manipulation of the environmental conditions. The protocols described in this investigation were optimized for the diatom species $T$. weissflogii; however, these techniques can be readily adapted to further investigate the physiological roles of ROS production in a range of phytoplankton, and how these may be affected by nutrient limitation, light, antioxidant capacity, and photosynthetic rates.

Because $\mathrm{H}_{2} \mathrm{O}_{2}$ is membrane permeable and can diffuse out of the cell, intracellular production of $\mathrm{H}_{2} \mathrm{O}_{2}$ that has not been scavenged through enzymatic processes can significantly contribute to the external ROS pool that our assays detect. On the other hand, the $\mathrm{O}_{2}^{-}$anion is charged, highly reactive, and membrane impermeable (Takahashi and Asada 1983). Thus, estimated $\mathrm{O}_{2}^{-}$generation rates represent extracellular production most likely via reduction of $\mathrm{O}_{2}$ by plasma membrane reductases (Davey et al. 2003). In combination, these two assay methods can provide simultaneous real-time data on total (gross) and extracellular ROS production based on these differing properties of $\mathrm{H}_{2} \mathrm{O}_{2}$ and $\mathrm{O}_{2}^{-}$, providing a quick, 
a

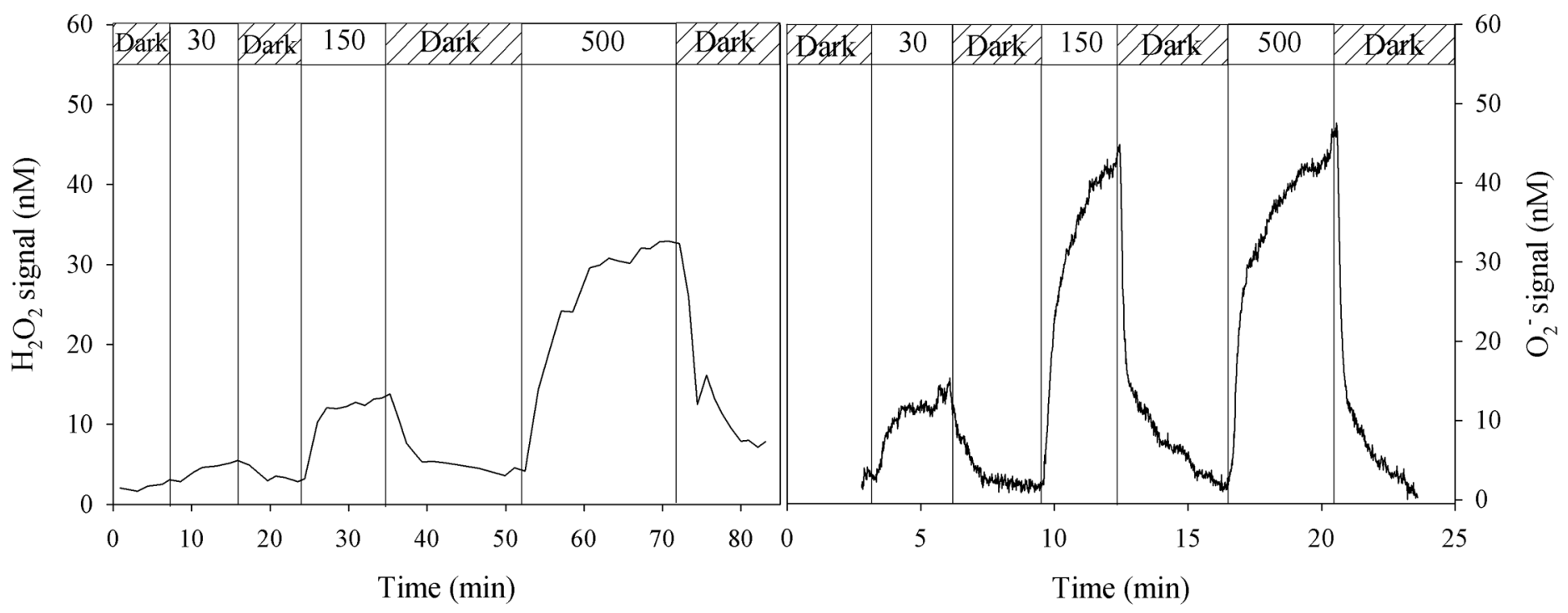

Fig. 6. Light-dependent ROS production by $T$. weissflogii. Typical light response data are shown for the production of $\mathrm{H}_{2} \mathrm{O}_{2}\left(\right.$ a) and $\mathrm{O}_{2}^{-}($b) when the inline filter unit was loaded with T. weissflogii and exposed to periods of light ( $\mu \mathrm{mol}$ photons $\mathrm{m}^{-2} \mathrm{~s}^{-1}$ ) as indicted in the bar at the top of each trace.

a

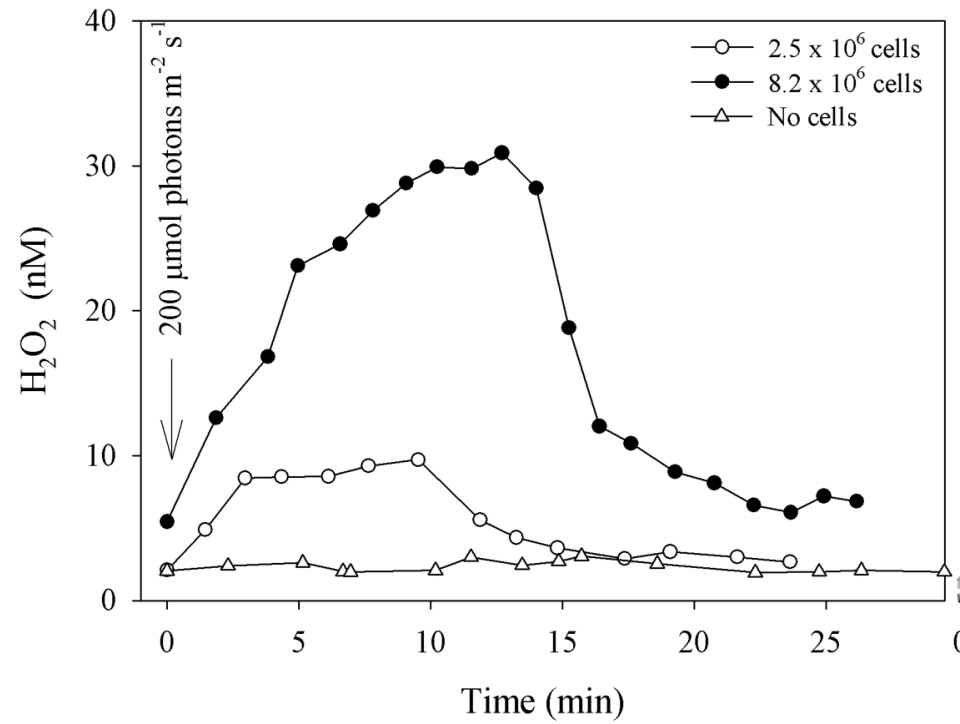

b

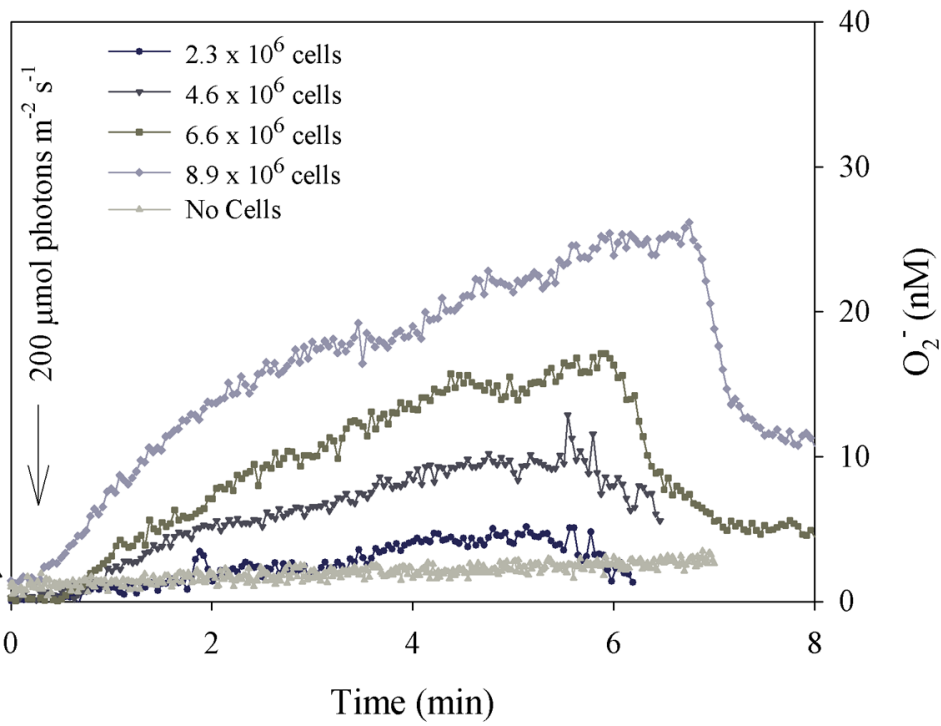

Fig. 7. Effect of phytoplankton biomass on ROS production. The cell density supported by the in-line filter unit was sequentially increased and lightstimulated $\mathrm{H}_{2} \mathrm{O}_{2}$ (a) and $\mathrm{O}_{2}^{-}$(b) production monitored for each biomass level.

simplistic means to resolve and estimate extracellular from gross cellular ROS production.

The methods we describe here should be applicable to a wide range of studies where high-sensitivity, real-time analysis of biological ROS production is required. We have demonstrated that the method can be used to assess ROS production in diatoms; however, these studies could be extended to a wide range of coastal and open-ocean phytoplankton species, though not all species may be amenable to the procedural manipulation described. The methods may also be used in field studies to estimate biological ROS production of natural populations in surface waters. Moreover, because the abiotic environmental conditions can be readily manipulated, these methods can now be used for a thorough investigation of the 
factors that control biological ROS production in aquatic ecosystems. The in-line filter unit that supports the phytoplankton cells can be easily modified to enable simultaneous non-invasive (fluorometric) measurements of photosynthetic physiology.

Finally, the methods described here have the potential to contribute to our understanding of the role phytoplankton ROS production plays in nutrient acquisition such as iron. Recently, Kustka et al. (2005) concluded that whereas iron(III) could be reduced by $\mathrm{O}_{2}{ }^{-}$produced by diatoms, this mechanism was unlikely to play a major role in iron assimilation, as they found no evidence for subsequent cellular uptake of the reduced iron in this organism. In contrast, Rose et al. (2005) suggested that $\mathrm{O}_{2}{ }^{-}$production by the coastal cyanobacterium Lyngbya majuscule facilitates increased iron uptake, speculating that this is a reasonably widespread process. To what degree biologically generated ROS contributes to trace metal speciation is an issue of great importance. The method we present here enhances our ability to address the role that phytoplankton in particular play in trace metal speciation, and to this end, we are further investigating the application of the technique described here in conjunction with flow injection-chemiluminescence detection of iron(II) (Bowie et al. 1998, 2002).

\section{References}

Asai, R., R. Matsukawa, K. Ikebukuro, and I. Karube. 1999. Highly sensitive chemiluminescence flow-injection detection of the red tide phytoplankton Heterosigma carterae. Anal. Chim. Acta 390:237-244.

Bielski, B. H. J., D. E. Cabelli, R. L. Arudi, and A. B. Ross. 1985. Reactivity of $\mathrm{HO}_{2} / \mathrm{O}_{2}^{-}$radicals in aqueous solution. J. Phys. Chem. Ref. Data 14:1041-1100.

Bowie, A. R., E P. Achterberg, R. F. C. Mantoura, and P. J. Worsfold. 1998. Determination of sub-nanomolar levels of iron in seawater using flow injection with chemiluminescence detection. Anal. Chim. Acta 361:189-200.

- $\longrightarrow$, P. N. Sedwick, S. Ussher, and P. J. Worsfold. 2002. Real-time monitoring of picomolar concentrations of iron(II) in marine waters using automated flow injectionchemiluminescence instrumentation. Environ. Sci. Technol. 36:4600-4607.

Butler, J., W. H. Koppenol, and E. Margoliash. 1982. Linetics and mechanism of the reduction of ferricytochrome $\mathrm{c}$ by the superoxide anion. J. Biol. Chem. 257:10747-10750.

Cooper, W. J., and R. G. Zika. 1983. Photochemical formation of hydrogen-peroxide in surface and ground waters exposed to sunlight. Science 220:711-712.

— E. S. Saltzman, and R. G. Zika. 1987. The contribution of rainwater to variability in surface hydrogen-peroxide. J. Geophys. Res. Oceans 92:2970-2980.

_, R. G. Zika, R. G. Petasne, and J. M. C. Plane. 1988. Photochemical formation of $\mathrm{H}_{2} \mathrm{O}_{2}$ in natural waters exposed to sunlight. Environ. Sci. Technol. 22:1156-1160.
, C. W. Shao, D. R. S. Lean, A. S. Gordon, and F. E. Scull. 1994. Factors affecting the distribution of $\mathrm{H}_{2} \mathrm{O}_{2}$ in surface waters, p. 391-422. In L. A. Baker [ed.], Environmental chemistry of lakes and reservoirs. American Chemical Society.

Croot, P. L., Streu, P. and A. R. Baker. 2004. Short residence time for iron in surface seawater impacted by atmospheric dry deposition from Saharan dust events. Geophys. Res. Lett. 31:L23S08 [doi:10.1029/2004GL020153].

_ , P. Laan, J. Nishioka, R. G. Zika, R. G. Petasne, and J. W. de Barr. 2005. Spatial and temporal distribution of Fe(II) and $\mathrm{H}_{2} \mathrm{O}_{2}$ during EisenEx, an open ocean mesoscale iron enrichment. Mar. Chem. 95:65-88.

Davey, M. S., D. J. Suggett, R. J. Geider, and A. R. Taylor. 2003. Phytoplankton plasma membrane redox activity: Effect of iron limitation and interaction with photosynthesis. J. Phycol. 39:1132-1144.

Dring, M. J. 2006. Stress resistance and disease resistance in seaweeds: The role of reactive oxygen metabolism. Adv. Bot. Res. 43:175-207.

Evans, C., G. Malin, G. P. Mills, and W. H. Wilson. 2006. The viral infection of Emiliania huxleyi (Prymnesiophyceae) leads to elevated production of reactive oxygen species. J. Phycol. 42:1040-1047.

Fridovich, I. 1985. Overview: Biological sources of $\mathrm{O}_{2}^{-}$. Methods Enzymol. 105:59-61

Gerringa, L. J. A., M. Rijkenberg, K. R. Timmermans, and A. G. J. Buma. 2004. The influence of solar ultraviolet radiation on the photochemical production of $\mathrm{H}_{2} \mathrm{O}_{2}$ in the equatorial Atlantic ocean. J. Sea Res. 51:3-10.

Goldstone, J. V., and B. M. Voelker 2000. Chemistry of superoxide radical in seawater: CDOM associated sink of superoxide in coastal waters. Environ. Sci. Technol. 34:10431048.

Kieber, D. J., B. M. Peake, and N. M. Scully. 2003. Reactive oxygen species in aquatic ecosystems, p. 251-288. In E. W. Helbling and $\mathrm{H}$. Zagarese [eds.], UV effects in aquatic organisms and ecosystems. Royal Society of Chemistry.

Kim, D., and others. 2000. Mechanism of superoxide anion generation in the toxic red tide phytoplankton Chattonella marina: Possible involvement of NAD(P)H oxidase. Biochim. Biophys. Acta Gen. Subj. 1524:220-227

- M. Watanabe, Y. Nakayasu, and K. Kohata. 2004. Production of superoxide anion and hydrogen peroxide associated with cell growth of Chattonella antiqua. Aquat. Microb. Ecol. 35:57-64.

Kustka, A. B., Y. Shaked, A. J. Milligan, D. W. King, and F. M. M. Morel. 2005. Extracellular production of superoxide by marine diatoms: Contrasting effects on iron redox chemistry and bioavailability. Limnol. Oceanogr. 50:1172-1180.

Lee, T. Y., N. Gotoh, E. Niki, K. Yokoyama, M. Tsuzuki, T. Takeuchi, and I. Karube. 1995. Chemiluminescence detection of red tide phytoplankton Chattonella marina. Anal. Chem. 67:225-228. 
McDowell, M. S., A. Bakac, and J. H. Espenson. 1983. A convenient route to superoxide ion in aqueous solution. Inorg. Chem. 22:847-848.

Millero, F. M. M. 2006. Chemical oceanography, 3rd Edition. CRC Press, Taylor \& Francis.

Moffett, J. W., and O. C. Zafiriou. 1990. An investigation of hydrogen-peroxide chemistry in surface waters of Vineyard Sound with $\mathrm{H}_{2}{ }^{18} \mathrm{O}_{2}$ and ${ }^{18} \mathrm{O}_{2}$. Limnol. Oceanogr. 35:12211229.

Petasne, R. G., and R. G. Zika. 1987. Fate of superoxide in coastal seawater. Nature 325:516-518.

and - 1997. Hydrogen peroxide lifetimes in South Florida coastal and offshore waters. Mar. Chem. $56: 225$.

Pipe, R. K. 1992. Generation of reactive oxygen metabolites by the hemocytes of the mussel mytilus-edulis. Dev. Compar. Immunol. 16:111-122.

Price, D., P. J. Worsfold, and R. F. C. Mantoura. 1994. Determination of hydrogen-peroxide in sea-water by flow-injection analysis with chemiluminescence detection. Anal. Chim. Acta 298:121-128.

Price, N. M., and F. M. M. Morel. 1998. Biological cycling of iron in the ocean, p. 1-36. In A. Sigel and H. Sigel [eds.], Metal ions on biological systems: Iron transport and storage in micro-organisms, plants and animals. Marcel Dekker.

Rose, A. L., and T. D. Waite. 2001. Chemiluminescence of luminol in the presence of iron(II) and oxygen: Oxidation mechanism and implications for its analytical use. Anal. Chem. 73:5909-5920.

and - 2005. Reduction of organically complexed ferric iron by superoxide in a simulated natural water. Environ. Sci. Technol. 39:2645-2650.

—, T. P. Salmon, T. Lukondeh, B. A. Neilan, and T. D. Waite. 2005. Use of superoxide as an electron shuttle for iron acquisition by the marine cyanobacterium Lyngbya majuscula. Environ. Sci. Technol. 39:3708-3715.

—, J. W. Moffett, and T. D. Waite. 2008a. Determination of superoxide in seawater using 2-methyl-6-(4methoxyphenyl)-3,7-dihydroimidazo[1,2-a]pyrazin-3(7H0one chemiluminescence. Anal. Chem. 80:1215-1227.

—, E. A. Webb, T. D. Waite, and J. W. Moffett. 2008b. Measurement and implications of nonphotochemically generated superoxide in the Equatorial Pacific. Environ. Sci. Technol. 42:2387-2393.

Smirnoff, N. 2005. Antioxidants and reactive oxygen species in plants. Blackwell Publishing.

Sutherland, M. W., and B. A. Learmonth. 1997. The tetrazoleum dyes MTS and XTT provide new quantitative assays for superoxide and superoxide dismutase. Free Radic. Res. 27:283-289.

Takahashi, M. A., and K. Asada. 1983. Superoxide anion permeability of phospholipid membranes and chloroplast thylakoids. Arch. Biochem. Biophys. 226:558-566.

Tan, A. S., and M. V. Berridge. 2000. Superoxide produced by activated neutrophils efficiently reduces the tetrazolium salt, WST-1 to produce a soluble formazan: A simple colorimetric assay for measuring respiratory burst activation and for screening anti-inflammatory agents. J. Immunol. Methods 238:59-68.

Ukeda, H., S. Maeda, T. Ishii, and M. Sawamura. 1997. Spectrophotometric assay for superoxide dismutase based on tetrazolium salt 3'-\{1-[(Phenylamino)-carbonyl]-3,4tetrazolium\}-bis(4-methoxy-6-nitro)benzenesulfonic acid hydrate reduction by xanthine-xanthine oxidase. Anal. Biochem. 251:206-209.

Vogel, A. I. 1989. Textbook of quantitative analysis, 5th edition. Longman Scientific \& Technical.

Wolfe-Simon, F., D. Grzebyk, O. Schofield, and P. G. Falkowski. 2005. The role and evolution of superoxide dismutases in algae. J. Phycol. 41:453-465.

Yocis, B. H., Kieber, D. J., and K. Mopper. 2000. Photochemical production of hydrogen peroxide in Antarctic Waters. Deep-Sea Res. I 47:1077-1099.

Yuan, J. C., and A. M. Shiller. 1999. Determination of subnanomolar levels of hydrogen peroxide in seawater by reagent-injection chemiluminescence detection. Anal. Chem. 71:1975-1980.

and - 2000. The variation of hydrogen peroxide in rainwater over the South and Central Atlantic Ocean. Atmos. Environ. 34:3973-3980.

and - 2001. The distribution of hydrogen peroxide in the southern and central Atlantic ocean. Deep-Sea Res. II 48:2947-2970.

and - 2005. Distribution of hydrogen peroxide in the northwest Pacific Ocean. Geochem. Geophys. Geosys. 6:Q09M02 [doi:10.1029/2004GC000908].

Zafiriou, O.C. 1990. Chemistry of superoxide ion-radical $\left(\mathrm{O}_{2}^{-}\right)$ in seawater. I. $p K^{*}{ }_{\text {asw }}(\mathrm{HOO})$ and uncatalysed dismutation kinetics studied by pulse radiolysis. Mar. Chem. 30:31-43.

Zheng, J., S. R. Springston, and J. Weinstein-Lloyd. 2003. Quantitative analysis of hydroperoxyl radical using flow injection analysis with chemiluminescence detection. Anal. Chem. 75:4696-4700.

Submitted 8 December 2008

Revised 13 July 2009

Accepted 3 August 2009 